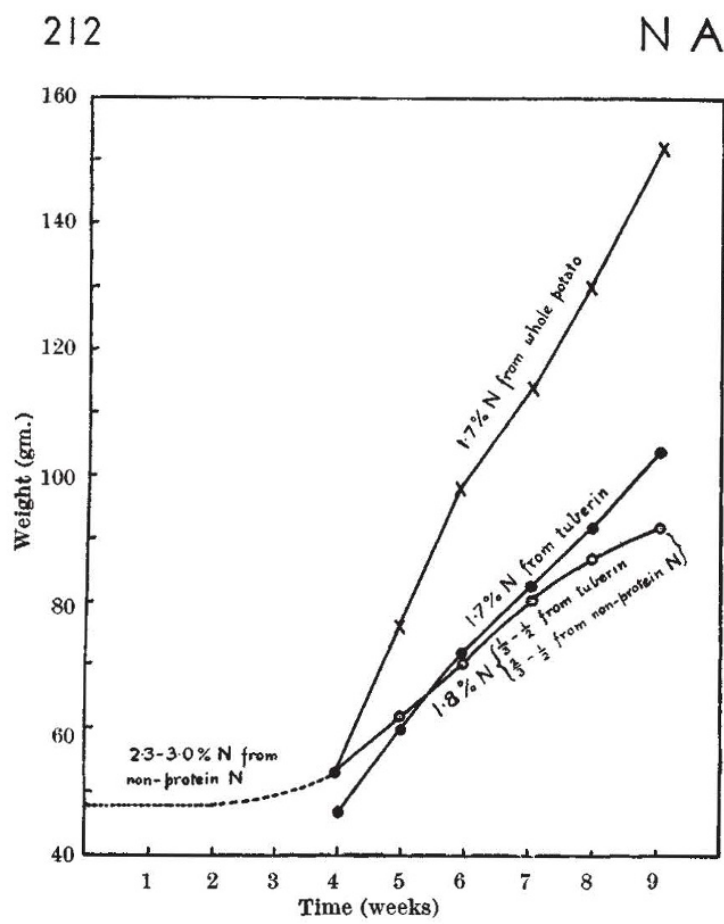

THE AVERAGE GROWTH-RATES OF YOUNG LITTER-MATE RATS RECEIVING DIETS COMPLETE WITH RESPECT TO ALL ESSENTIA NOTRIRNTS FXOEPT PROTHIN, SHOWING THE RELATIVE NUTRITTV VALUE OF VARIOUS NITROGENOUS CONSTITUENTS OF THE POTATO

Chick and Cutting ${ }^{8}$ and Chick and Slack ${ }^{15}$ have shown, however, that although the non-protein fraction is alone incapable of supporting growth, yet the mixture of protein and non-protein nitrogen in the whole tuber possesses a nutritive value, as measured by its growth-supporting capacity for young rats, at least equal to that of the isolated tuberin. The obvious explanation of this result is not possible, since no supplementation between tuberin and the non-protein nitrogen could be demonstrated when the two fractions were isolated and fed in various proportions. In the accompanying growth charts, obtained in one such experiment, the broken line represents the average weight-change of a group of six litter-mate weanling rats receiving a diet complete with respect to all essential nutrients except nitrogen. The latter was derived entirely from protein-free potato juice and fed at a level of $2 \cdot 3$ per cent nitrogen on the dry weight for three weeks and at a level of 3.0 per cent nitrogen for a further week. There was little change in weight on these diets. At the end of a month, three of the six rats were given a diet containing 1.7 per cent nitrogen derived from whole potato, and the other three a diet containing 1.8 per cent nitrogen derived from a mixture of tuberin and non-protein nitrogen in the proportions in which they occur in the whole potato. The average growth-curve of a group of three rats receiving a diet in which all the nitrogen is supplied at a level of 1.7 per cent nitrogen derived entirely from tuberin is included from another experiment.

It is difficult to account in terms of amino-acid content for the superiority of the whole potato over tuberin as a source of dietary nitrogen. The small amount of unidentified nitrogen which cannot be extracted from potato residue (about 8 per cent of the total potato nitrogen and almost certainly protein) may be exerting an effect, or the potato may contain minute amounts of material similar to streptogenin, which Woolley ${ }^{16}$ has shown to be a peptide-like factor
February 7, 1948 vol. 161

stimulating the growth of $L$. Casei and obtained by tryptic digest of certain proteins of which it is an integral part. Otherwise it would appear that the potato contains further substances which, though neither proteins nor amino-acids, are capable of replacing or supplementing these in the diet.

I wish to thank Dr. Harriette Chick for permitting me to include the results of the experiments shown in the graph, and should also like to record my appreciation of the helpful advice and encouragement I have received from Sir Charles Martin and Prof. A. C. Chibnall.

${ }^{1}$ Oshorne, T. B., and Campbell, G. F., J. Amer. Chem. Soc., 18, 575 (1896).

2 Neuberger, A., and Sanger, F., Biochem. J., 36, 862 (1942)

${ }^{3}$ Groot, E. H., Janssen, L. W., Rentie, A., Oosterhius, H. K., and Trap, H. J. L., Voeding, 6, 124 (1946).

- Sjollema, B., and Rinkes, I. J., Hoppe-Seyler's Z. physiol. Chem. 76, 369 (1912).

- Groot, E. H., Voeding, 6, 153 (1945).

- Gale, E. F., Nature, 157, 263 (1946).

'Kon, S. K., Biochem. J., 22, 261 (1928).

${ }^{8}$ Chick, H., and Cutting, M. E. M., Lancet, ii, 667 (1943).

- Tristram, G. R., Biochem. J., 40, 721 (1946).

${ }^{10}$ Macpherson, H. T., Biochem. J., 40, 470 (1946).

${ }^{11}$ Lugg, J. W. H., Biochem. J., 32, 2114 (1938).

12 Hess, W. C., and Sullivan, M. X., Ind. Eng. Chem., Anal. Ed. (November 1945)

1s Rees, M. W., Biochem. J., 40, 632 (1946).

14 Vickery, H. B., J. Biol. Chem., 65, 657 (1925).

${ }^{18}$ Chick, H., and Slack, E. B., unpublished work (1944).

16 Woolley, D. W., J. Biol. Chem., 162, 383 (1946).

\section{NEW CHEMICAL AND PHYSICAL LABORATORY AT THE ROYAL AIRCRAFT ESTABLISHMENT, FARNBOROUGH, HANTS}

YHEMICAL research in the Royal Aircraft Estab. $\mathcal{A}$ lishment commenced under Dr. J. E. Ramsbottom in the early years of the First World War, but until very recently the accommodation for chemical and physical research was by no means adequate for present-day needs. However, a new laboratory has recently been completed and was formally opened on October 29 by Mr. G. R. Strauss, Minister of Supply. In his introductory address, the director of the Royal Aircraft Establishment, Mr. W. G. A. Perring, outlined the growth of chemistry at the Establishment and summarized the outstanding contributions of the Chemistry Department to aeronautical research. A specification for a new laboratory was originally drawn up by Dr. Ramsbottom and his staff before the Second World War, and in his capacity of war-time head of the Chemistry Department, Prof. W. F. K. Wynne-Jones was responsible for the detailed layout of the laboratory and for pressing forward the extended scheme. Much valuable advice was received from Sir Ian Heilbron of the Imperial College of Science and Technology, London, and throughout the planning and constructional period Mr. R. B. Twiss, a member of the Chemistry Department staff, has been the general adviser on all research requirements to the architect, Mr. Oliver Law, the consulting engineers, Messrs. A. H. Barker and Partners, and the contractors, Messrs. Trollope and Colls.

The new laboratory was designed in 1944 and constructed during the period 1945-47. Its general layout represents an attempt to provide up-to-date facilities for both basic research in the chemical and 


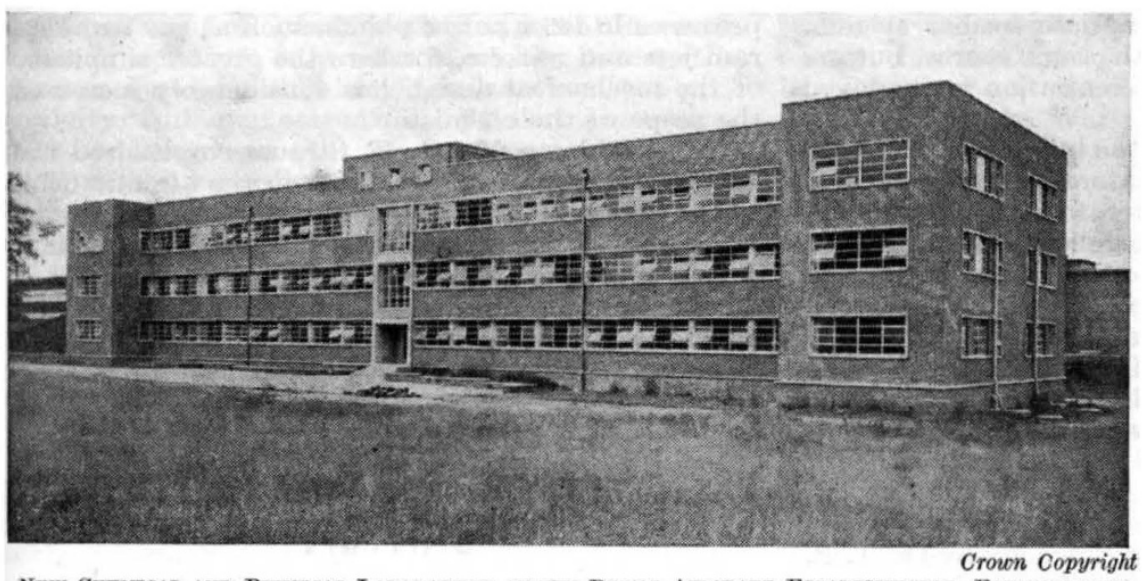

New Chemical and Physical laboratory at the royal amoraft Estabuishment, Farnorough to the first-floor corridor. This double-height room is of fire-resisting construction, isolated from the building by two more steel doors giving access from the ground-floor cor. ridor. There are two more entrances from out. side the building directly opposite these isolating doors.

Individual laboratories in the whole block are designed to make ohanges of function easy to accomplish; specialized layout has therefore given place to flexibility, with the exception of a few special

physical fields and more applied studies of aviation problems of a chemical and physical nature. Well. sited, easily accessible by new roads in front and rear, the laboratory comprises a single block, in plan dumb-bell-shaped and almost symmetrical, the long centre section terminating in two transverse wings. The overall length is about $220 \mathrm{ft}$., the width of the centre part $44 \mathrm{ft}$., and of the wings $65 \mathrm{ft}$., the total floor area being of the order of 40,000 sq. ft. Excavation of the whole centre section provides considerable basement area for spectrographic laboratories, service control rooms, air-conditioning equipment, refrigerators, a liquid-air plant and bulk store. The wings are not excavated and their solid floors permit heavier plant installation than suspended floors.

The main building rises three floors above the base. ment, and has a flat roof surmounted by a small central laboratory, lift room, and the fume-extraction plant, the latter comprising four large fan chambers and their associated acid-resisting ductwork. Most of the floor area is available for experimental work, all services being carried up into the central laboratory.

The building construction is robust; the reinforced concrete framing (columns, beams and floors) was cast in situ. The external walls are filled with $13 \frac{1}{2}$-in. solid brickwork above ground-floor level; basement retaining walls are of reinforced concrete, brickfaced. The foundations are adequate for structural weight plus a uniform loading of $200 \mathrm{lb}$. per sq. ft. for all suspended floors.

Along the centre section of the building, columns are regularly spaced at $10 \mathrm{ft} .7$ in. centres, with spacing in wings appropriate to the greater spans. The central corridors on each floor, including the basement, extend from wing to wing and are $7 \mathrm{ft}$. wide, so that along the length of the block subdivision by transverse brickwork partitioning provides rooms which are multiples of the unit bay size (internally $10 \mathrm{ft} .3 \mathrm{in.}$ by $16 \mathrm{ft} .9 \mathrm{in}$.). The wings, $62 \mathrm{ft}$. by $20 \mathrm{ft}$. internally, can be used as single rooms or subdivided, the extra width providing for large centre benches as in the analytical laboratory, or for bulky equipment as in the X-ray section.

Ceilings are generally $10 \mathrm{ft}$. $9 \mathrm{in}$. high (basement $8 \mathrm{ft} .9$ in.), but in the centrally disposed 5 -bay pilotplant laboratory the first floor has been omitted to give headroom of $22 \mathrm{ft}$. for tall apparatus such as stills, there being a gallery around three sides at first-floor level, accessible via two iron stairways within the room, with an emergency exit steel door rooms, for example, the X-ray and electron micro. scopy and the textile sections.

Special attention has been given to stores, all three of which are near the lift, those on the finst and second floors having separate lift access gates. Laboratories making greatest demands on the stores are as near as possible to them; offices and other rooms lie farther along the corridors, towards the south end of this building. In general, the ground floor is allotted to the more physical operations; the first, except for the analytical laboratory, is largely administrative; and the second devoted chiefly to chemical work requiring efficient fume disposal above roof-level.

The electrical and mechanical services follow the general flexibility requirement, considerable subdivision with ease of accessibility simplifying maintenance and facilitating modifications with minimum. disturbance. Adequate service outlets and floor drain points, either blanked off as future provision or continued to required positions, are provided in nearly every room. Conversion of function, for example, offices into laboratories, is thus straightforward. Some standardization of fittings also has improved adaptability to varying requirements.

In more detail, the distributed services are cold and hot water, medium pressure steam, compressed air, gas, three- and single-phase 400/230-V. A.c. and 210-V. D.c. ; low-voltage supplies are provided from any A.c. point by variable transformers and rectifiers, with local batteries where necessary:

Distribution of non-electric services to rooms is via horizontal sub-mains suspended along corridor ceilings on each side, separately controlled branches feeding outwards from the centrally disposed main risers. Branches off the sub-mains enter rooms at high level and are there valved; each room is thus independent of others.

The electrical services are similarly distributed, vertical feeders supplying separate A.C. and D.c. multiple plug-in busbar systems an ground and second floors, and distribution boards elsewhere. By this means, separately fused branch connexions may be made at 2 -ft. intervals even with busbars alive without disturbance to more than the single laboratory concerned; leads run in flexible conduit to separate distribution boards in roams; the whole system is thus extremely adaptable. Each laboratory is fitted with specially designed combination plug and terminal box outlets, the circuits being well subdivided. Additional supplies may be abteined from 
a fresh tapping of the appropriate busbar system. Lighting points are fed from the same source, but are separately fused. Colour differentiation is employed. for all services.

Heating and ventilating of the building are effected by low-pressure steam radiators and the central plenum installation, the latter forcing filtered and tempered air through ducting following the route of the general services. Vitiated air is thus displaced, each room having inlet and exit grilles at high level. The ducts pass centrally along corridors, the whole being enclosed by false ceilings, with removable access panels along the whole length, the voids on each floor communicating with the exit air shaft discharging at roof-level.

A brief summary of the field of chemical and physical research covered by the Chemistry Departmont was given at the opening ceremony by Dr. T. P. Hughes, the present head of the Department. As a specialist department of the R.A.E., the Chemistry Department must be prepared to offer chemical advice and services to all departments of the Royal Aircraft Establishment and to certain departments of the Ministry of Supply ; both these functions have been discharged with some notable successes in the past. Much of the work is necessarily of a short-term and ad hoc nature; but roughly speaking about half the effort of the Department is directed along fairly long-term lines and includes a healthy proportion of basic chemical and physical research.

The Chemistry Department is responsible for much of the development and application of non-metallic materials to aircraft, and under Mr. H. W. Hall is a section specializing in the chemistry and physics of such solids as plastics, rubber, wood and adhesives. Recent developments in high-speed flight have emphasized the value of maintaining smooth surfaces on thin highly stressed wings, and it has been considered that reinforced plastic structures might possess many production and operational advantages over the conventional metal wing. To develop this specific application, and also to examine the possibilities of plastic structures for all airframe requirements, a section under Mr. J. E. Gordon is attempting to make a few large-scale structures in reinforced plastics. A related field is that of textiles, where a section under Mr. J. W. W. Dyer is covering certain aspects of the development and performance of textiles and proofed fabrics.

The physics and chemistry of the many special fluids used in civil and military aircraft, such as paints, fuels, hydraulic fluids, lubricating oils and greases, are being studied in a section under Dr. E. W. J. Mardles. Much of the work is concerned at present with the rheological behaviour of these fluids. The assessment and reduction of fire risks in aircraft is the major function of a section directed by Mr. W. G. Glendinning. A section under Dr. J. D. MainSmith covers miscellaneous chemical problems, chiefly of an inorganic nature. Among many other successes, this group developed the simple chemical carbon monoxide indicator which is widely used for aircraft cabin-contamination tests.

The chemistry of the reactions liberating energy in various forms of aircraft power plant is being investigated in a section under Dr. W. G. Parker. In the same manner as the development of piston engines and their fuels has been materially assisted by the understanding of the combustion process gained by some twenty years of physico-chemical research, it is hoped to obtain some insight into the combustion processes in later power plants, such as gas turbines, ram jets and rockets, for here the greater simplicity of the mechanical design has considerably increased the scope of the chemist.

In his address, Mr. G. R. Strauss emphasized the importance of scientific research in the aircraft field, and declared that the Government would continue to give every support to aeronautical research and development. In the new laboratory he hoped that the chemists and physicists would find congenial working conditions for the important part they have to play in aeronautical research of the future.

\section{GOVERNMENT RESEARCH IN BRITAIN}

WHILE the veil of secrecy drawn for the most part over the activities of the Department of Scientific and Industrial Research since the spring of 1939 remains unlifted, and we still await the resumption of publication of the annual reports of the Department and even the appearance of the long. promised review of its war-time activities, pronouncements regarding administrative developments are made in diverse ways and sometimes to strange audiences. The address of the Lord President of the Council to the North Herts Labour Party at Letchworth on January 14, containing the important announcement regarding the development of a scientific centre at the new town of Stevenage, is a recent example. Mr. Morrison prefaced his announcement by stating that the Government is eager to see science supporting enterprise in the national effort for economic recovery and independence. It proposes to bring to public enterprise new ideas and progressive development by making full use of the unrivalled scientific brains of Britain, sweeping away the old isolation of science and the tendency to look at scientific workers as people not needed in industry or only needed in the 'back room', or as long-haired. old gentlemen cut off from worldly affairs. The Government is taking steps, he said, to bring science into the forefront of British industry, and does not believe that industry can give the nation what it wants in increasing abundance at decreasing costs unless science becomes more of a partner.

Mr. Morrison referred to the recent increase in the number and the effectiveness of the research associations in industry, and to the way in which the National Coal Board has brought science into the coal-mining industry at the top level and in every area. He looked to the time when every British worker will be conscious that he has a scientific man close at hand to make his work easier and less unpleasant, and to help him to get a better result. Although it would be some time before British industry could be re-equipped, even existing plant could be made much more productive by the assist. ance of science.

Mr. Morrison emphasized that time would also be required before fundamental research now being carried out could show results in industry; in the meantime, he said, we must rely chiefly on the more effective use of the vast amount of scientific knowledge which already exists, but which has not yet been fully applied in British industry, and on harnessing the social sciences to help managements and workers in their daily problems. Here the Lord President instanced the contribution of housing research under 